\title{
Türkiye' de 1957-1960 Arası Dönemde Demokrat Parti Ve Chp Arasındaki Tartışmalarda Güvenlik Söylemi
}

\author{
DOI: 10.26466/opus.833529
}

*

\begin{abstract}
Cemile Burcu Kartal *
* Dr Öğr.Üyesi. Atatürk Üni,Kamu Yönetimi Böl,Siyaset ve Sosyal Bilimler ABD,Erzurum/ Türkiye E-Posta: burcu.kartal@atauni.edu.tr

ORCID: $\underline{0000-0003-1575-6612}$

Öz

Bu makalede amaç, 1957-1960 yılları arasında ana muhalefet partisi olan Cumhuriyet Halk Partisi ile iktidarda bulunan Demokrat Parti'nin kendi söylemlerinde ve rakiplerine karşı yönelttikleri propagandalarında hangi konuları milli güvenlik kapsamı içine soktukların ve güvenlik söylemlerini incelemektir. Çalışmada 1957-1960'l yılların seçilmesindeki sebep, DP'nin iktidarının son döneminin olması, iktidar ve muhalefetin çatışmasının artması ve Uluslararası ortamda yaşanan değişimler açısından önemli bir dönem olmasıdır. Söz konusu dönemin koşulları gereğince iki partinin dış politika konusundaki temel görüşleri birbiriyle çok çelişmemişse de; dönemin kavramlarıla 'milli emniyet', 'milli birlik ve bütünlük' anlayışlar iç siyaset alanında birbirlerine zıt bir çizgide seyretmiştir. Bu amaçla da iki partinin güvenlik anlayışları incelenmeye çalışılacaktır. Çalışmanın ilk bölümünde, kavramların tanımlanmasına, literatürde güvenlik tanımın nasıl bir değişim yaşadığına ana hatlart ile değinilecek, daha sonra iç ve dış siyasal ortamın kısa analizine yer verilecek; ikinci ve üçüncü bölümde ise, hem DP'nin hem de CHP'nin uluslararası ve iç politikayı ilgilendiren konulardaki güvenlik anlayışları ve söylemleri incelenecektir. Tartışmalar, dönem basınına yansıyan haberler ve liderlerin konuşmalar üzerinden değerlendirilecektir.
\end{abstract}

Anahtar Kelimeler: Güvenlik Söylemi, Güvenlik Politikası, Demokrat Parti, CHP 


\title{
Security Discourse in the Discussions Between the Democratic Party and the Republican People's Party (1957-1960) \\ *
}

\begin{abstract}
This article's goal is to analyze which issues the Democratic Party, that was in power between the years 1957 and 1960, and the Republican People's Party, which was the main opposition party, included in the scope of national security in their own discourse and in their propaganda against their rivals, and their security argues. The reason for choosing the years 1957-1960 in this study is that it was the last period of power of DP (Democratic Party), it is an important period in terms of the increase in the conflict of ruling party and opposition party and the changes in the international environment.

Despite the fact that the basic views of these two parties on foreign policy didn't contradict one another under the conditions of the period in question; concepts of "national security", "national unity and integrity" with the concepts of the period followed an opposite line in the field of domestic politics. To that end, the security understanding of these two parties will be tried to be examined. In the first part of the study, the definition of the concepts, the change in the definition of security in the literature will be discussed, and then a short analysis of the domestic and foreign political environment will be mentioned; in the second and third sections, both DP and CHP's understanding of security and discourses on international and domestic policy issues will be examined. The discussions will be evaluated over the news appeared in the press of the period and the speeches of the leaders
\end{abstract}

Keywords: Security Discourse, Security Policy, Democratic Party, CHP 


\section{Giriş}

Güvenlik kavramı 1940'lardan itibaren stratejik çalışmalar adıyla doğup, Uluslararası İlişkilerin alt disiplinine dönüşerek, günümüzde de güvenlik çalışmaları alanının içinde yer almaktadır. 1940 ve 1980'li yıllara kadar güvenlik, devletleri ilgilendiren askeri sorunlar çerçevesinde devletlerin uyguladığ güç politikaları ile özdeşleşmiştir. (Açıkmeşe, 2014, s.241-242)

En basit tanımıyla güvenlik amacı, var olma amacı ile ilgili olup, doğrudan anavatanın savunulmasına gerek bırakmayacak önlemlerin alınması olarak anlaşılmaktadır. Genel olarak bir ülkenin güvenlik amacı bir başka ülkenin veya ülkelerinki ile çatışma halindedir. Güvenlik amacı şartlardaki değişiklikten etkilenmektedir. Güvenlik ile siyasal rejim arasında bir ilişkinin söz konusu olduğu, bir başka deyişle demokratik ülkelerin birbirleriyle çok az savaştıkları çalışmalarda ortaya çıkmaktadır. Ancak son dönemde yapılan güvenlik çalışmalarında ülke güvenliği açısından önemi çeşitli durumlarda karşımıza çıkan ekonomik kapasite, ekonomik bağımlılık/karşılıklı bağımlılık kavramları, küreselleşen dünyada daha belirgin bir biçimde analizlere konu olmaktadır. (Sönmezoğlu, 2005, s.274-276)

Nitekim son dönemdeki literatüre baktığımızda 1980'lerden itibaren güvenlik kavramı devletleri ilgilendiren askeri sorunların ötesinde anlaşılmaya başlanmıştır. 1980'lerin sonunda güvenliğin askeri sorunların haricinde çevre sorunları, yoksulluk, nüfus fazlalığı, siyasi baskılar, suç, göç, ekonomik istikrarsızlık, hastalık, vb sorunlarla tehdit edildiği anlayışı gelişmiştir. (Açımeşe,2014, s.242)

Makalede, 1957-1960 yılları arasinda iktidarda bulunan Demokrat Parti(DP) ile ana muhalefet partisi olan Cumhuriyet Halk Partisi'nin (CHP) kendi söylemlerinde ve rakiplerine karşı yönelttikleri propagandalarındaki güvenlik söylemlerini ve hangi konuları milli güvenlik kapsamı içine soktukların incelenecektir.

1957-1960'lı yıllar DP'nin iktidarının son dönemi ve Uluslararası ortamda yaşanan değişimler açısından önemli bir dönemdir. Muhalefetin DP'ye yönelik eleştirileri iyice artmış, sadece dış politika alanında değil iç politikadaki birçok konu da milli güvenliği tehdit olarak söylemlerde yer almaya başlamıştır. Gerek muhalefet gerekse iktidar arasında çatısmalar daha da keskinleşmiştir. 
Söz konusu dönemin koşulları gereğince iki partinin dış politika konusundaki temel görüşleri birbiriyle çok çelişmemişse de; dönemin kavramlarıyla 'milli emniyet', 'milli birlik ve bütünlük' anlayışları iç siyaset alanında birbirlerine zit bir çizgide seyretmiştir.

Bu amaçla da iki partinin güvenlik anlayışları incelenmeye çalışılacaktır. Bu bağlamda ilk bölüm, kavramların ana hatları ile tanımlanmasına ve iç ve dış siyasal ortamın kısa analizine yer verilecek; ikinci bölümde ise, hem DP'nin hem de CHP'nin konuyla ilgili söylemleri incelenecektir. Tartışmalar dönem basınına yansıyan haberler ve liderlerin konuşmaları üzerinden değerlendirilecektir.

\section{Güvenlik Nedir?}

Güvenlik kavramının tanımı tartışmalı bir konudur. Hatta bazen devlet yetkilileri bu kavramın kesin sınırlar çizilerek tanımlanmasına yanaşmamaktadır, çünkü özellikle Soğuk Savaş süresince güvenlik çalışmalarının kapsamını askeri alan belirlemiştir. (Baldwin, 1997, s.9)Güvenlik çalışmaları alanı 1940'larda ABD'de doğmuş, başlangıçta Amerikan merkezli olup, her hangi bir disipline bağlı değildir, zaman içinde ise uluslararası ilişkilerin alt disiplini haline gelmiştir. Soğuk Savaş koşulları içinde sadece askeri konuların devlet merkezli analizine yoğunlaşan alan iki kutuplu sistemin sona ermesiyle, devlet dışı aktörleri ve askeri nitelik taşımayan sorunları da analiz kapsamına dâhil etmiştir. 1930'ların başından 1980'lerin ortasına kadar Uluslararası disiplinin en önemli okulu olan realist okulun söylemleri güvenlik çalışmalarının da temeli olmuştur. Realistler güvenlik kavramını devlet merkezli ele almışlardır. (Açıkmeşe,2014, s.246) Bu durum Neorealistlerde de fazla değişmemiş ve güvenlik kavramını devletle ilişkilendirmişlerdir. Neorealistlere göre güvenlik, en önemli hedeftir. "Takımlar şampiyonluğu kazanmak için, devletler güvenlik için yarışırlar." (Baldwin, 1997, s.10)demektedirler. Onlara göre daha güvenli olanlar, diğer devletlere nazaran oyunu uluslararası siyaset arenasında daha iyi oynuyorlar demektir. (Baldwin, 1997, s.10)

Soğuk savaşın sona ermesiyle devlet merkezli görüşler, güvenliğin tanımlanmasında yetersiz kaldı. Böylelikle yeni arayışlara yönelindi. Bu da 1990'larda ulusal sistemin eleştirisinin doğmasına neden oldu. (Lantis, 2002, s.89). Bu yeni görüş kimliklere, sosyal rollere gönderme yapmakta ve güvenlik kavramını siyasal kültürle bağlandırmaya çalışmışır. Bu dönemde ortaya 
çıkan yapısalcı ve kültürel görüş, realistlerin çalışmalarıyla günümüz disiplinlerinin uyumlandırılmasında stratejik kültürü önemli bir destekleyici olarak kullandı (Lantis, 2002, s. 113) ve uluslararası güvenlik konusunda kimlikleri, sosyal rolleri ve sosyal çevreyi hesaba kattılar. Sosyal yapılar içindeki yerel aktörlerin etkileşimlerini kabul ederek; Uluslararası sistem düzeylerinde devlet hareketlerinin sosyal yapıları üzerine yoğunlaşmışlardır. (Farrell, 2002, s. 49-52.; Açıkmeşe, 2014, s. 246-254))

Wolfers ise daha farklı bir yaklaşımla, güvenliğin her zaman arzulanır bir şey olmadığını, bazı statükodan memnun olmayan devletlerin, değerlerini korumak yerine yeni değerler kazanmaya yöneldiklerini ileri sürmüştür. Ona göre güvenlik, "değerleri elde etmede hasarın düşük olasılı̆̆ı" dır. (Baldwin, 1997, s.11,13.)

"Kim için güvenlik?" konusuna Soğuk Savaş döneminin düşünürleri, ortak güvenlik açıklaması getirmiş; ancak dönemi koşulları ağırlığını yitirmeye başlayınca, soruna askeri olmayan boyutta eklenmiş; bireylerin ve sosyal grupların güvenliği de hesaba katılmaya başlanmıştır. (Bilgin, 2003, s. 204.)

Hangi değerler için güvenlik konusunda geleneksel olarak siyasal bağımsızlık ve ülkesel bütünlükler değer olarak korunur. Ancak kimi zaman, ekonomik refah, otonomi ve psikolojik etmenlerde eklenmektedir. Bu konuda şöyle bir yaklaşım da mümkündür: azgelişmiş güvenliği yaklaşımı ikili bir ayrıma gitmiştir. Buna göre gelişmiş devletler, statükonun değerlerinin korunmasını hedef olarak belirlerken; azgelişmiş ülkeleri, ekonomik, siyasal ve çevresel faktörleri de kendi güvenlik anlayışlarına dâhil etmektedirler. (Bilgin,2003, s. 206.)

Bunların yanı sıra, ne kadar güvenlik, hangi tehditlerden, hangi amaçlarla, ne kadar süre için ve bunların bedeli konularında da ayrım söz konusudur. Özetle bugün artık tek bir güvenlik kavramından söz etmek mümkün değildir. Günümüzde bireysel, ulusal, bölgesel, uluslararası, küresel güvenlik ile askeri, siyasi, toplumsal, ekonomik, çevresel, insani güvenlik kavramları bir arada bulunmaktadır. Güvenlikten ne anlaşılacağı tehdide ve aktöre bağlı olarak değişmektedir. Bu anlamda da güvenlik farklı yaklaşımlarca farklı tanımlanmaktadır. (Açıkmeşe, 2014, s. 244). Özellikle siyasi tercihlerde ekonomik faktörlerin, toplumsal refaha ilişkin konuların daha fazla rol oynamaya başlaması ve teknolojinin askeri faaliyetler açısından kazandığı önem, günümüz dünyasında ekonomik ve teknolojik imkânların da bir ülkenin güvenliği 
açısından taşıdığı önemi açıkça ortaya koymaktadır. (Sönmezoğlu, 2005, s.274-276)

\section{7-1960’lı Yıllardaki Uluslararası Siyasal Ortam}

İkinci Dünya Savaşı'nın ardından 1970'lere kadar olan uluslararası ilişkiler tarihi, iki karşıt ideolojiye bağlanmış ABD ile Sovyetler Birliği'nin dünyaya etki kurmak çabasının tarihi olarak özetlenebilir. Diğer devletler, bu iki süper güç etrafında kümelenmişlerdir. Ancak bu kümelenme, sadece diğer kutbun büyük gücüne karşı yer almakla sınırlı değildir. Özellikle ABD ve SSCB d1şındaki devletler açısından kendi bölgesel çıkarları bağlamında sırtını büyük bir güce dayamak isteğinden de kaynaklanmaktadır. (Sander, 1996, s. 181)

Türkiye ise ilk modernleşme çabalarıly birlikte zaten Batıya ve Batının siyasal değerlerine yakın durmuş; II. Dünya Savaşı́nın ardından ise bu eğilim artarak devam etmiştir. Bunun yanı sıra SSCB'nin Boğazlar üzerindeki emelleri, Türkiye'yi Batı bloğunun parçası olmaya yöneltmiştir. Truman Doktrini ve Marshall Planı ile de destek görmüştür. . (Sander, 1996, s.231-234).

Türkiye'nin 1957-1960 yılları arasındaki dış politikası ise, kabaca SSCB ile ilişkiler, $A B D$ ve NATO ile ilişkiler, Yunanistan ve Ortadoğu ile ilişkiler olarak gruplandırılabilir. Bu süreçte tavizsiz bir şekilde Batı yanlısı bir politika izledi. İlk olarak SSCB ile ilişkilere baktığımızda, Stalin'in ölümünün ardından göreli bir yumuşama söz konusuydu. 30 Mayıs 1953 tarihli nota ile SSCB, II. Dünya Savaşının ardından gelen isteklerinden vazgeçtiğini bildirmiş ve ilişkilerin iyileşmesi umudunu dile getirmiştir. Türkiye bu notaya blok politikasıyla yanıt verdiyse de; ekonomik ilişkiler başladı ve artarak devam etti. 1957'deki Suriye bunalımı ve 1958'deki Irak'taki darbe SSCB ile ilişkileri oldukça gerginleştirdi. 1957 yılında Türkiye'de Jüpiter füzelerinin konuşlandırılmasının gündeme gelmesiyle de, U-2 kriziyle doruğa ulaşacak 1962'ye dek sürecek bir füze krizi başlamıştır. Ancak 31 Ekim 1959'da Kruşçev, ilişkileri iyileştirme isteğini bir kez daha dile getirdi. Zorlu'nun 28 Şubat 1959 'da yaptığı konuşması bu isteğe olumlu yaklaşıldığını göstermekteydi. 1960 yılında görüşmelerin başbakanlık düzeyine çıkarılması gündeme gelmişti ancak 15 Temmuzda yapılması planlanan görüşme 27 Mayıs darbesi nedeniyle gerçekleşemedi. (Tellal, 2005, s.511) İkinci Dünya Savaşının ardından ABD ile ilişkiler esasen Truman doktriniyle başlamıştır. Türkiye, ABD açısından Doğu Akdeniz ve Ortadoğu bölgelerinin güvenliği için önemliydi. Özellikle 
NATO'ya üye olduktan sonra Türkiye'nin diş politikası bu çerçevede gelişti. Doğu Akdeniz'de Balkan Paktı'nın, Ortadoğu'da ise Bağdat Paktı'nın kurulmasına öncülük etti. (Armaoğlu, 2002, s.518-521.)

Türkiye NATO'ya, 25 Haziran 1950'de başlayan Kore Savaşı'na BM emrine asker vermesinin de etkisiyle, 21 Eylül 1951 tarihinde davet edildi. 19 Şubat 1952 tarihinde TBMM, Türkiye'nin NATO'ya katılmasını onayladı. NATO'ya üyelik, Türkiye açısından sadece SSCB tehlikesinden korunmak için değil; aynı zamanda NATO'nun askeri, ekonomik yardımlarından faydalanmak açısından da önemliydi.

Türkiye-ABD arasında 1952-1960 yılları arasında 54 ikili anlaşma imzalanmıştır. Bu anlaşmaların askeri olanlarına paralel olarak Türk Silahlı Kuvvetlerinin kadro, kuruluş ve teşkilatı, eğitimi savaş doktrin ve kuralları, NATO'nun da etkisiyle Amerikan ordusuna benzer şekilde yapılandırıldı. (Erhan, 2005, s.556)

SSCB ve ÇHC'nin liderliğindeki komünizmin tehlike olarak kabul edilmesiyle; bununla başa çıkabilmek amacıyla ABD başkanı Eisenhower başkanlığında Ekim 1953'te 'Yeni Bakış Stratejisi' yürürlüğe kondu. Buna göre, kitlesel karşılık stratejisi uygulanacak; Doğu Avrupa ülkelerine yönelik bir propaganda faaliyeti yürütülecek ve Truman Doktriniyle başlatılan çevreleme politikası çerçevesinde Orta Doğu ve Asya-Pasifik bölgelerinde yeni ittifaklar kurulacaktı. Türkiye'deki Amerikan üsleri bu dönemde açıldı. SEATO'nun kurulmasıyla Asya-Pasifik planları gerçekleşti. Orta Doğu'da ise, 1955 yılında kurulan Bağdat Paktı'yla bunun gerçekleştirilmesi hedeflendi. 9 Ocak 1957 'de onaylanan bu doktrin, Ortadoğu'da SSCB ile ABD'nin karşı karşıya gelmelerini simgelemektedir. Bu doktrinin benimsenmesiyle giderek azalmakta olan Amerikan yardımları arttı ki; hükümetin en işine gelen husus buydu. Ancak, bu doktrini benimsemeyen diğer Orta Doğu ülkeleriyle ilişkiler gerginleşti. Türkiye ilk kez topraklarındaki ABD üslerinin NATO amaçları dişında kullanılmasına izin verdi. (Erhan, 2005, s. 522-576)

14 Temmuz 1958 Irak Darbesi de dönemin önemli olaylarındandır. Darbe, Bağdat Paktı gibi örgütlerin ABD'nin doğrudan katılımı olmadan istikrarlı şekilde süremeyeceğini gösterdi. Türkiye, bunun üzerine ABD'den Orta Doğu'nun barış, güvenlik ve istikrarının sağlanması için yardım istedi. Bunun üzerine 28 Temmuz 1958' de Londra'da, İngiltere, İran, Pakistan, Türkiye başbakanlarıyla ABD dışişleri bakanının katılımıyla bir toplantı düzenlendi. Pakt üyeleri bundan sonra sadece "doğrudan saldırılara" karşı değil; ülke 
içinden gelebilecek "dolaylı saldırılar" karşısında da birlikte hareket edeceklerini, "ortak güvenlik için özgür dünyanın diğer üyeleriyle işbirliği yapılacağını" vurguladılar. (Erhan, 2005, s.569.)ABD, Pakta fiilen katıldı. 24 Mart 1959'da Irak' ın Paktan çekildiğini açıklamasıyla 21 Ağustos 1959'da örgütün ismi CENTO olarak değiştirildi. 14 Temmuz 1958 yılında General Kasım tarafından Irak'taki Kral Faysal yönetimindeki monarşi bir darbeyle yıkıldı. Bağdat Paktında bu durum görüşülerek darbenin, dışarıdan kaynaklanan y1kıcı faaliyetler sonucu olduğuna karar verildi ve Eisenhower Doktrini doğrultusunda ABD'nin Irak'a müdahalesi istendi. Türkiye, Irak'taki yeni durumun tanınmayacağını bildirdi ve askeri müdahale üzerinde durmaya başladi. Ancak bunun SSCB'yi harekete geçireceğinden endişelenen ABD ve İngiltere, Türkiye'ye engel oldu. Sonunda 31 Temmuz 1958'de Türkiye, yeni yönetimi tanıdığını açıkladı. Ancak yeni yönetim, 1959'da Bağdat Paktından çekildi. (Erhan, 2005, s.569.)

1950-1955 yılları arasında Türkiye ve Yunanistan'da benzer siyasal, ekonomik ve sosyal gelişmeler yaşanmıştır. İki ülke içinde ulusal çıkarları önce ABD'yle sonra NATO'yla özdeş algilanmaktaydı. Yakınlaşma, 1952 yılının Ocağında karşılıklı ziyaretlerle başladı. Bu yakınlaşma 28 Şubat 1953 yılında Balkan Paktı'nın imzalanmasına neden oldu. Pakt, 1954 yılında ittifaka dönüştü. Ancak Kıbrıs sorununun ortaya çıkması bu iyimser havanın dağılmasina neden oldu.

Kıbrıs sorunu 1954 yılında Rumların self-determinasyon ilkelerinin uygulanması için BM'e başvurmasıyla uluslararası niteliğe bürünmüştür. BM bu başvuruyu reddetmiştir. Bunun üzerine Kıbrıs'ta Rumlar tarafından 1955 y1lından itibaren sabotaj eylemleri başlatıldı. Bunun üzerine İngiltere başkanlığında, Türkiye ve Yunanistan'ın katılacağı bir konferans düzenlenmesi teklif edildi. Londra Konferans1, 29 Ağustos 1955'te çalışmalara başladı. Türkiye bu konferansta ilk kez Kıbrıs'a yönelik bir politika oluşturdu ve Kıbrıs'ın Türkiye'nin güneyine yakınlığından dolayı hayati bir öneme sahip olduğu, başka bir ülkenin eline geçmesi halinde ve özellikle bu ülkenin Ege'deki adalara da sahip olması durumunda Türkiye' yi kuşatma altına rahatlıkla alabileceği; bu nedenle Türkiye'nin buna müsaade etmeyeceği bildirildi. Ancak toplantı başarılı olamadı. Bunun üzerine Türkiye tarafından taksim tezi ortaya atıldı ve CHP tarafından da desteklendi. 1958 yılının yazında Kıbrıs'ta yaşanan çatışmalar Türkiye ve Yunanistan'ı savaşın eşiğine getirmişti. Bu anlaşmazlığın 
devamı, Soğuk Savaş ortamında ABD'yi tedirgin etmekteydi ve sorunu çözmek için bağımsızlık formülü önerdi. Sonuçta Aralık 1958'de taraflar enosis ve taksim tezlerinden vazgeçtiklerini ve bağımsızlık formülünde anlaştıklarını açıkladılar. 1959 yılında Zürih ve Londra Anlaşmalarıyla Türkiye, Yunanistan ve İngiltere ile organik bağlar kuran, bağımsız bir Kıbrıs kuruldu. (Armaoğlu, 2002, s.531-533.)

Dönemde Türkiye Orta Doğu ile ilişkilerini Batı́nın sözcüsü olarak sürdürmüş; bu durum oradaki bağımsızlık girişimlerini görmezden gelmesine neden olmuştur. Arap devletleri arasında Türkiye'nin bu tutumu, emperyalizm sözcüğü olarak değerlendirilmiştir. 1945-1949 yılları arasında Arap devletleriyle yakınlaşma dönemi olmuşsa da; 1950'den sonra Batı'nın bu bölgeyle ilgili planlarının sadık bir uygulayıcısı haline gelmiştir. Bu politika çerçevesinde 2 Nisan 1954'te Türk-Pakistan Dostane İşbirliği Anlaşması imzaland1. Menderes ABD'ye yaptığı bir ziyarette 'İsrail' in varlığı gerçeğini tanımak Arap devletleri için bir gerekliliktir' (Fırat-Kürkçüoğlu, 2005, s.622)demesi Türkiye'nin Orta Doğu politikasını gözler önüne sermekteydi. Ardından 24 Şubat 1955'te, Bağdat Paktı olarak bilinen Türkiye-Irak Karşılıklı İşbirliği Anlaşması imzalandı. Suriye anlaşmaya, İsrail yanlısı görünümü nedeniyle katılmadı ve Mısır'la bir pakt imzaladı. Bu durum Türkiye ile Suriye ilişkilerini gerginleştirdi. Ancak ilişkilerin gerginleştirilmemesi için ABD'den gelen uyarı sonucunda ilişkileri bir ölçüde yumuşadı. (Fırat-Kürkçüoğlu, 2005, s.622.)

Bağdat Paktı, Arapları batıya yakınlaştırma, daha fazla ekonomik yardım gibi beklentileri boşa çıkarırken; bölgeye SSCB'nin girmesini de kolaylaştırmıştır. Nasır' in etkisindeki milliyetçi hareketler Lübnan ve Ürdün'de de etkili olmuştu. Irak darbesinin de cesaretlendirdiği iç isyanlar, Lübnan liderinin ABD'den yardım istemesine yol açtı. Bunun üzerine ABD, Eisenhower Doktrinini ilk kez uygulayarak 'Lübnan'ın bağımsızlık ve toprak bütünlüğünü sürdürmek için Lübnan Hükümetine yardım etmek' gerekçesiyle bir kuvvet gönderdi. (Fırat-Kürkçüoğlu, 2005, s. 633). Bu hareket Türkiye'deki iktidar tarafından onaylandı. Ürdün ise Irak'taki darbeden en fazla etkilenen devletti. Irak'a Arap Federal Birliği anayasası ile bağlıydı. Ürdün Kralı Hüseyin darbenin Ürdün'e sıçramasından endişeliydi. Batıdan yardım talep etti ve olumlu karşılandı. Türkiye' ye göre bu faaliyetler, 'dışarıdan tertiplenen yıkıcı faaliyetlere karşı korunma’ idi. (Fırat-Kürkçüoğlu, 2005, s.633-634.) 


\section{7-1960'lı Yıllardaki İç Siyasal Ortam}

1954 yılından sonraki genel seçimin normal zamanı 1958 Mayıs 'tı ancak ekonomik durumun kötüye gitmesi ve bu durumun halkın oyları üzerinde olabilecek olumsuz etkisini kırmak için iktidar, ciddi bir kaygı duymuş ve seçimlerin 27 Ekim 1957 tarihinde yapılmasını kararlaştırmıştır. (Yıldırım, 2019, s.73)

Genel seçimler 27 Ekim 1957' de yapılmış DP'nin oyu \% 47 ile mecliste 424 sandalyeye sahip olmuştur. CHP: 178, CMP: 4 ve HP:4 milletvekili ile meclise girmiştir 1957 seçimleri sonrasında ortaya çlkan en önemli gelişme oylarının artmasıyla CHP'nin daha sert ve aktif bir muhalefet yürütmeye başlamasıdır. (Bulut, 2990, s. 131)

1957-1960'li yıllar bir önceki Menderes dönemleri gibi genel olarak ekonomide dışa hesapsız açılmanın yol açtığı, dış ticaret açıları ve giderek artan dış borçlara sahne olmuştur. Bunun kaynağı, Marshall Planı gereğince hedeflenen bölgeyi dünya ticaretine açmak ve Türkiye'nin gida ve hammadde sağlayıcısı haline getirmek hedefleriydi. (Oran, 2005, s. 487.)

Buna ekonominin plan ve program yapılmadan yürütülmesi de eklenince, 1954 yılından itibaren ekonomi çökmeye ve giderek dışa daha bağımlı hale gelmeye başladı. Kötü hava koşulları nedeniyle tarım ürünleri, oldukça düşmüş; 1954'te, tarım ürünü 1953 yılının \% 80'i seviyesinde kalmıştır. Dolayısıyla ihracat imkânları daralmış; bu durum ithalatı da kısmayı gerekli kılmıştır. Ancak bu uygulamanın doğrudan sonucu, piyasadaki malların azalması, fiyatların yükselmesi ve karaborsa olmuştur. Özellikle şeker gibi maddeler piyasada bulunmaz olmuştur. Ekonomik durumun kötüye gitmesi, muhalefetin güçlenmesine yol açacak, DP yöneticilerinin bundan dolayı telaşa düşmesi, meclisteki çoğunluğu nedeniyle en kolay yol gibi görünen baskı uygulamalarına yönelmelerine neden olacak, uygulanılan baskı arttıkça, yönetime duyulan öfke artacak; öfkenin artışı DP'yi daha büyük bir korku ve paniğe sürükleyerek baskının daha çok arttırılmasına sebep olacaktır. Bu zincirleme reaksiyon devam ettikçe, DP yöneticilerinin ezeli korkusu olan darbe tehlikesi belirerek; darbe korkusu en sonunda darbeye neden olacaktır. (Eroğul, 2003, s.208; Erdemir, 263-274; Pars, 2005)

Menderes, 10 Şubat 1956'da yaptığı bir konuşmada, ana muhalefet partisini komünistlikle, vatanı dışarıya jurnallemekle, milli çıkarlanı kundakla- 
makla suçlamıştır. (Cumhuriyet, 11 Şubat 1956.)Menderes, zaten 1953'ün Ekiminden beri muhalefete savaş ilan etmeye karar vermiş; (Zafer, 25 Ekim 1953.) CHP malvarlığına el koyabilmek için gerekli kanunu çıkarmıştır. (Cumhuriyet, 15 Aralık 1953, Pars; 2005)

Menderes, 25 Mayıs 1957'de Sivas'ta yaptığı bir konuşmada, erken seçim olacağını ilan etmesi üzerine muhalefette, Demokrat Parti iktidarına karşı, CHP, CMP, HP işbirliği çabaları baş göstermiştir. DP Devlet Bakanı Emin Kalafat, bu üç muhalefet partisinin ortak bildirgesini bozgunculuk olarak nitelendirmiştir. (Zafer, 9 Ekim 1957; Pars, 2005.)

DP seçimler öncesinde, İnönü ve CHP'ye karşı, II. Dünya Savaşının ardından On İki Adanın sessizce Yunanistan'a bırakıldığını, eğer DP başta olmasaydı Kıbrıs'ında aynı akıbete uğrayacağını savunarak ve fırsat buldukça fabrika, tesis temel atma törenlerine katılarak ekonomik alanda pembe bir tablo çizme çabasıyla seçim kampanyasını yürütmekteydiler. (Cumhuriyet, 14 Ekim 1957.) Konuşmalarında Menderes, muhaliflere 'milli bozguncular' diye hitap etmekteydi. (Cumhuriyet, 20 Ekim 1957.)

Muhalefetin seçim propagandasında ağırlık verdiği hususlar, ekonomik sıkıntılar ve özgürlüklerin yokluğuydu. İnönü seçim kampanyasını, “Türkiye siyasal ve ekonomik buhran içindedir" sloganiyla yürütmekteydi.

27 Ekim 1957 tarihinde yapılan genel seçimlerle, DP bir kez daha çoğunluğu sağlayarak seçimlerin galibi olarak çıkmasına rağmen, oylarında ciddi bir düşüş yaşanmıştır. Dönemde yaşanan siyasal bunalım da ordu içerisinde hareketlenmeye neden olmaktaydı. İnönü de, konuşmalarında bu hareketlenmenin sinyallerini vermeye başlamıştı. Kendini Atatürk'ün mirasının bekçisi kabul eden ordu, özellikle NATO ve ABD yardımları sayesinde de DP'nin Kemalist geleneklere ihanet ettiğini inancındaydı. DP yöneticilerinin de en çekindiği kesim, orduydu. 14 Temmuz 1958 tarihinde Irak'ta yönetime karşı bir darbe yapılan darbe de iktidarın darbe korkularını alevlendirmişti. (Eroğul, 2003, s.223, Pars,2005, s. 150)

Bu sırada ekonomide durum giderek kötüleşmekte, zamlar çoğu kez \% 100 'ü bulmaktaydı. Batıyla olan ilişkiler dolayısıyla da dış borç da bulunmamaktaydı. Getirilen ciddi ölçüdeki zamlar, halk arasında huzursuzluk yaratmaya başlamıştı. Ekonominin dar boğazdan çıkarılamaması nedeniyle Batıdan tekrar yardım talep edilmiş; yeni krediler karşılığında, kendilerine türlü denetim hakları taahhüt edilmişti. (Pars, 2005, s. ) (Cumhuriyet, 4 Ağustos 1958.) 
26 Ağustos 1958'de Menderes, toplumun büyük bir kısmını siyaset dış1 bırakacak olan, partilerin ocak ve bucak teşkilatların ilga etmeyi de planlamaktaydı. Menderes, 6 Eylül 1958'de Balıkesir'de ve 21 Eylül 1958'de İzmir'de yaptığı konuşmalarda, "Ben halk adamıyım, muhalefet yaratan güçler, benim karşımda olduğundan halkın da düşmanıdır. Bu düşmanlar, iktisadi kalkınma nedeniyle içine düşülen geçici sıkıntıları sömürmektedir. Ben bu nifak yuvalarını ezerek, halkın aldanmasını önlemeliyim. Halk bunu anlayışla karşılayacaktır. Bu amaçla her türlü vasıtayı kullanmak da hakkımdır." (Eroğul, 2003, s. 225.) diyerek, toplumun büyük bir kısmını siyaset dış1 bırakacak olan, partilerin ocak ve bucak teşkilatlarını kapatma planını savunmuştu. (Cumhuriyet, 27 Ağustos 1958.)

İnönü de konuşmasında, “demokrasiye paydos demeye DP Genel Başkanının gücü yetmeyecektir... kanun dışında hareket eden idare amirleri, özellikle adalet mensupları, elbette hesap verecektir. Doğru yoldan ayrılmış olanları kimse kurtaramaz." demekteydi. (Cumhuriyet, 23-25 Eylül 1958.)

Menderes' in bu politikasının karşısında muhalefet partileri, birleşerek bir güç birliği oluşturma kararı almıştır. (Cumhuriyet, 19 Kasım 1958.)Hükümet ise, bu güç birliği hareketini Haçlı ordusuna benzeterek, karşıllğında Vatan Cephesini kurmuş ve geniş bir taban yaratmayı amaçlamıştı. Menderes konudaki fikrini ilk kez, 12 Ekim 1958 tarihinde, Manisa İl Kongresinde, ‘Vatan Cephesi' nutkuyla açıklamış; “...politika ve ihtirastan kurtulmuş vatandaşların kin ve husumet cephesine karşı bir vatan cephesi kurmalarını" istemiştir. (Cumhuriyet, 13 Ekim 1958.) Cephe, 1958 Kasımından itibaren kurulmaya başlanmıştır. (Ağaoğlu, 1967, s.127.) Bu tarihten itibaren halk, Güç Birliği Ocakları ve Vatan Cephesi Ocakları olarak iki hasım bloğa ayrılmıştır. (Yıldırim, 2019, s.175-178)

12-15 Ocak 1959 tarihleri arasında CHP'nin 14. Kurultayı toplanmış; muhalefetin mücadele hedeflerini belirleyen "İlk Hedefler Beyannamesi" kabul edilmiştir. İnönü, 29 Nisan 1959’da “Büyük Taarruz" adını verdiği bir propaganda seferi başlatmıştır. İlk durak Uşak'tı. Daha sonra Manisa, İzmir ve son olarak İstanbul'a gelmiş; ancak çatışmalara neden olmuştu. DP'li gazete CHP'ni gayri meşru ve fesat yuvası olmakla suçlamakta ve kapatılmasını istemekteydi. (Cumhuriyet, 16 Mayıs, 14 Eylül 1959; Zafer, 14 Eylül 1959.)

Nisan 1960'da Tahkikat Komisyonunun, tam bir baskı mahiyetinde olan görev ve yetkilerini düzenleyen kanun (Resmi Gazete,1960, sayı: 10491 (28 Nisan 1960), Kanun No: 7468, Kabul Tarihi: 27 Nisan 1960.) kabul edildiği 
andan itibaren ise, darbe için geri sayım başlamış oldu. Kanunun kabulü, İstanbul'da 28 Nisan'da, İstanbul Üniversitesi öğrencilerinin ve Ankara'da 29 Nisan ve 5 Mayıs'ta gösterilerin yapılmasına neden oldu. Sonuçta hükümet, sıkıyönetim ilan etmekle ve her türlü toplantıyı sıkıyönetimce yasaklamakla yetinmek zorunda kalmıştır. Olaylardan bunalan Menderes, 11 Mayıs'ta meclis, 11 günlüğüne tatile sokularak Ege gezisine çıkmış; her durakta yoğun bir halk sevgisi ve tezahüratlarla karşılanmıştı. (Cumhuriyet, 16 Mayıs 1960.)İktidarının milli iradeye dayandığına ve arkasında büyük kalabalıkların desteğini bulduğuna inancı, onun yaklaşan darbeyi görmezden gelmesine neden olmuştu. (Pars, 2005)

21 Mayıs' ta Harp Okulu öğrencileri, büyük bir sessiz yürüyüş düzenledi. 25 Mayıs'ta ise Menderes, Eskişehir gezisi için uçaktan indiğinde, onu karşılayan bir grup subay sırtını dönerek tepkilerini gösterdi. Bu gezi, Menderes'in son gezisi olmuştur.

27 Mayıs sabahı saat 04:36'da Albay Alpaslan Türkeş, Ankara Radyosunda, "Türk Silahlı Kuvvetlerinin ülkenin yönetimin, ele aldığını" duyurarak Demokrat Parti dönemini sonlandırmıştır. Silahlı kuvvetler adına yönetime el koyan "Milli Birlik Komitesi", yayınladı̆̆ 13 numaralı bildiriyle, yeni bir anayasanın ilanına kadar siyasal partilerin her türlü faaliyetlerini yasakladığını bildirmesiyle de; Türkiye' de çok partili rejime bir süreliğine ara verilmiş; Menderes ve çalışma arkadaşları tutuklanarak, yargılanmak üzere Yassıada'ya gönderilmiştir.

\section{CHP ve DP'nin Dış Siyaseti İlgilendiren Konulardaki Güvenlik Anlayışı}

İlk olarak dış politikada CHP'nin güvenlik anlayışına baktığımızda İsmet İnönü'nün görüşleri bu anlayışın özetini bize vermektedir: "II. Dünya Savaşından sonra müttefikler arasında ortaya çıkan ihtilaf ve ayrima da bizim hayati meselelerimizi ortaya çıkarmıştır. Bu menfaatleri korumak için muhtaç olduğumuz desteği Batı âleminde ve Amerika'da bulduk. O zamandan beri, memleket müdafaasının Batı Demokrasileri topluluğu içinde müşterek mükellefiyetle mümkün olacağı hakikati her vesile ile teeyyüt etmiştir... Bizim için, husule gelen ittifaklar içinde sadakatle ve fedakarlıkla memleket emniyetini sağlamak lazımdır." (İnönü, 1956, s.63.)

1957 yılında ABD ile imzalanan İstimlak ve Müsadere Anlaşması muhalefetin büyük tepkisine yol açtı. Anlaşma esasen ABD şirketlerinin Türkiye'de yatırım yapmaları karşılığında tanınan ayrıcalıkları içermekteydi. 
Türkiye'de yatırım yapan ABD şirketleri ile Türk şirketleri arasında çıkabilecek bir anlaşmazlığa, ABD hükümetinin müdahil sıfatıyla taraf olabilme olanağı getirmekteydi. Bu anlaşmanın onaylanması için Ocak 1959 yılında TBMM'de yapılan görüşmelerde muhalefetin tepkisi büyük oldu.

Muhalefet, DP'nin Amerikan yardımlarını partizan amaçlarla kullandığını iddia etmekteydi. Hükümlerinin kapitülasyonları hatırlattığını savunmaktaydılar. (Erhan, 2005, s. 561.)Inönü 6 Mayıs 1960 tarihinde NATO gazetecileriyle yaptığ bir röportajda, “...dost memleketlerden gelen yardımlara ihtiyacımız vardır. Amerikan vatandaşı bu yardımı kendi kazancından veriyor. Milletçe müteşekkir kalırı ve kummetini biliriz. Ancak, bu yardımın baskı rejiminin devamı için vasıta olarak kullanıldığı da aşikârdır. Yardımı isteriz, ama teşvik etmemesini de isteriz" (İnönü, 103.)açıklamasını yaparak bu konu hakkındaki görüşünü dile getirmiştir.

Diğer bir tartışma da Irak'ta Darbe ve CENTO konusunda yaşandı. CHP ve İnönü'ye göre, “CENTO Irak'ın ayrilmasindan sonra daha sadece bir şekilde önemini arttırmıştır. İkili ittifaklar, Amerika'nun ilgisini daha yakından göstermesi firsatın vermiştir. Ancak CENTO içindeki sorumluluklarmmızm hiçbiri, NATO içindeki durumumuza tesir etmemelidir. CHP, Türkiye'nin CENTO'de muhafazasm esash bir gaye bilmektedir." (İnönü,1956, s. 64.)

Ancak DP, CHP'yi Irak'taki olayları kullanarak halkı isyana teşvik etmekle suçlamıştır. DP Meclis Grubunun yayınladığı bildiri bu suçlamaları açıkça ortaya koymuştur. "CHP'liler, Irak olayların ele alarak, TBMM'nin ve hükümetinin meşruiyetini ve istikrarnı şiddet yolu ile tahrip etmenin mümkün, hatta lazım olduğu kanaatini uyandırmaya müncer olabilecek çok tehlikeli bir yola girmişlerdir....memleketi kanunsuz, devletsiz ve otoritesiz idare ediliyormuş gibi göstermek tarafin tutarak, meşru sayılamayacak bir mücadele yolu takip etmektedirler. CHP, kendisi iktidarda olmadığı için TBMM'ni ve iktidarı tanımamaktadır. ...14 Temmuz 1958 günü patlak veren Irak hadiselerinden beri, durum büsbütün tahripkâr bir manzara arz ediyor." (Erer, 1963, s.341). Onlara göre Irak'ta krallığın sona ermesi ile CHP'de Türkiye'nin diktatörü saydıkları Menderes ve ekibinin aynı şekilde bir ihtilalle kurtulacaklarını propaganda etmeye başlamışlardı. Bunun üzerine Irak hadiselerinin istismar edilmesini önlemek ve orduda herhangi bir harekete mani olmak için Türk Kara Kuvvetlerinde de değişiklik yapıldı. 26 Ağustos 1958 tarihinde Kara Kuvvetleri Komutanlığına Korgeneral Cemal Gürsel getirildi. 
1958 Lübnan ve Ürdün Sorunları da muhalefetin iktidara yönelik eleştirilerinin arttığı diğer bir konu oldu. ABD’nin ‘Lübnan' ın bağımsızlık ve toprak bütünlüğünü sürdürmek için Lübnan Hükümetine yardım etmek' gerekçesiyle bir kuvvet gönderilmesi ve Türk hükümetinin bunu olumlu karşılayarak; üslerini $\mathrm{ABD}^{\prime}$ ye kullandırmak istemesi muhalefetin büyük tepkilerine yol açtı. Ancak Zorlu'nun buna yanıtı eleştirileri anlamsız bulduğu yönündeydi.

Kıbrıs Meselesi de iktidar ve muhalefeti karşılaştıran diğer konu idi. 3 Mayıs 1957 tarihinde Bursa'da yaptığı bir konuşmada Menderes, Kıbrıs konusunda muhalefeti, açıkça hükümetin tarafını tutmamakla ve konu hakkında birlik oluşturulmaması konusunda eleştirdi. (Cumhuriyet, 4 Mayıs 1957.)

Hürriyet Partisi ise, iktidarın Kıbrıs meselesini bir iç politika sorunu haline çevirmesinden yakınarak; politikasını neden 'Kıbrıs Türktür'den, 'taksim'e çevirdiğini açıklamasını istedi. (Cumhuriyet, 5 Mayıs 1957.)

Londra Antlaşması, 28 Şubat 1959 tarihinde TBMM'de tartışmaya açıldı. İnönü, kararda kuvvetli dostların tesirli nasihatlerinin payı olduğunu ileri sürmekteydi. Taksimden fedakârlık yapıldığı görüşü egemendi. Dış işleri Bakanı Zorlu'nun eleştirilere yanıtı, fedakârlık yapıldıysa, adanın tümünün alınmamasından fedakârlık yapıldığını; taksimi terk etmekle bir fedakârlık yapılmadığını, Kıbrıslı Türklere egemenlik temin eden ve Türkiye'nin güvenliğini teminat altına alan bir çözümün tercih edildiği şeklinde olmuştur. (F1rat, 2005, s.614.)

Muhalefet, TBMM'nin 16 Haziran 1958 günü Kıbrıs meselesi hakkında aldığ 1 "Türkiye, Kıbrıs meselesi Yunanistan tarafindan ortaya çıarıldı̆̆ından beri kendi hayati menfaatleri ve Kıbrıs'taki 120 bin Türk'ün hayat ve bekasin bu kadar yakından alakadar eden bu meselede son derece ağırbaşl ve uzlaşmacı hareket etmiş ve Yunanlilar tarafindan ortaya atılan taksim fikrini kabul etmiştir...Türk cemaatine, Rum cemaatinin tahakkümü altında birakılmayacă̆g hususunda teminat vermek la$z ı m d \imath r . . . "$ kararına iktidarın riayet etmediği ve TBMM'ni tanımayarak emrivaki hareket ettiği suçlamasını yöneltmiştir. (Bekata, 1959 s. 43-44.)

Bu iddiaya cevaben Zorlu, böyle bir kararın ancak hükümet seviyesinde alınabileceğini bildirmiştir. 5 Mart 1959 Türk-Amerikan Güvenlik İşbirliği Anlaşması da muhalefetin sert tepkilerine neden oldu. 28 Temmuz 1958 Londra kararlarına uygun olarak imzalanan ikili anlaşmaya göre ABD, Türkiye'ye yönelik "doğrudan" veya "dolaylı" saldırı durumunda hükümetin 
talebiyle, silahlı güç kullanmak da dâhil olmak üzere her türlü yardımı yapacakt. Ancak bu yardım, ABD anayasasına engel teşkil etmemeli ve Eisenhower Doktrini'ne uyumlu olmalıydı. Anlaşmanın onaylanması için Şubat 1959'da TBMM'de görüşülmesi sırasında özellikle bu "dolaylı" saldırı konusu muhalefetin sert tepkilerine neden oldu. (9 Mayıs 1960'da TBMM'de onayland1.)

CHP milletvekilleri TBMM Dışişleri Komisyonunda hükümet üyelerinden, 'dolaylı saldırı' ibaresiyle neyi kastettiklerini açıkça ifade etmelerini istedilerse de; komisyon üyeleri, dolaylı saldırının gizli ve yıkıcı faaliyetleri de içerdiğini ama güvenlik gerekçesiyle daha fazla açıklama yapılamayacağı cevabını vererek soruyu geçiştirdiler. $\mathrm{CHP}$, bu kavramın geniş yorumundan endişe etmekteydiler. Onlara göre bu ifade geniş bir yorumla, DP iktidarına yönelik halk hareketlerini de kapsama tehlikesi içermekteydi. Böylece ABD, yardıma çağrılabilecekti. Lübnan olayına gönderme yapılarak, ABD’nin bu anlaşmayla Türkiye'nin içişlerine müdahale hakkı içerdiğini savunuyorlardı. (Erhan,2005, s.569).

Muhalefeti destekleyen Ulus gazetesinde yazllanlara göre, Türkiye'nin zaten NATO üyesi olduğu ve Türk-ABD ilişkilerinde bu anlaşmanın yeni bir boyut kazandırmadığı, NATO anlaşmasında komünizmin dolaylı saldırısından bahsedilmediğini dolayısıyla anlaşmanın, NATO amaçlarının ötesinde hedefler içerdiği savunulmuştur. Bu hususlara karşı Dışişleri Bakanı Zorlu, anlaşmanın Orta Doğu'nun savunulması için kurulan örgütü desteklemek amacıyla yapıldığını altında başka anlam aranmaması gerektiğini ileri sürmüştür. (Erhan,2005, s.570.)

\section{CHP ve DP'nin İç Siyaseti İlgilendiren Konulardaki Güvenlik Anlayışı}

İç siyaseti ilgilendiren bazı konular, iktidar ve muhalefet açısından farklı değerlendirilerek, milli menfaatler ve bağımsızlık çerçevesine sokulmuştur.

Buna göre CHP'nin faaliyetleri, DP tarafından 'halkı isyana teşvik' olarak algılanırken; DP'nin aldığı kararlar, CHP tarafından 'partizanlık ve serbest seçim ve özgürlüklerin yokluğu' olarak değerlendirilmiş ve milli menfaatlere aykırı kabul edilmiştir. 


\section{CHP'nin Güvenlik Algılayışı}

İnönü, yabancı bir muhabire verdiği demeçte, "iç düzen sağlanamadıkça dışta etkin bir rol oynamaz" demekle, iç siyasal ortamın dışa karşı bağımsızlık ve bütünlük açısından önemini vurgulamıştır.

İnönü, partisinin güvenlik anlayışını 18 Ekim 1959 yılında İstanbul Beyoğlu İlçe kongresindeki konuşmasında şöyle dile getirmiştir: "Güvenlik toplum hayatına yön veren kuralların başında, vatandaşa güven ve emniyet sağlamak gelir. Siyasi emniyet konusunda ve her çeşit iktisadi hayatta vatandaşın fiili olarak eşit şefkat ve himaye görmesi toplumun tüm meselelerinin üstünde bir öneme sahiptir. Güven unsurunun iç ve dış politikada kazandığı öneme uygun olarak vatandaşın eşit kanun hükümleri ve devletin her kapısında eşit muamele görmeleri ile mal ve can emniyeti konusunu sarsılmayan bir kararllikla takip etmek gerekmektedir. Bunu să̆lamanin yegâne yolu, serbest ve eşit bir seçim müessesesinin kurulmasıdır." (İnönü, 1956, s.20.)Ona göre cumhuriyet müesseselerinin sarsılması, milli bünyeyi de temelinden sarsacaktır. ${ }^{1}$ (İnönü, 1956, s.120.)

İçerde ve dışarıda siyasi, iktisadi ve içtimai bakımdan kuvvetli bir devlet olmanın yolu, vatandaşın eşit muamele gördüğü, basın hürriyetinin olduğu, görüş alışverişinin faydalı şekilde işlediği, dürüst seçimlerin yapıldığı demokratik rejim ve idarenin gerçekleşmesidir. ${ }^{2}$ (İnönü, 1956, s.26.)

Demokratik rejimin kurtulması meselesi, memleket için hayati önem kazanmıştır. (İnönü,1956, s. 45.)

İnönü, 11 Ekim 1959 tarihinde İstanbul Kadıköy İlçe kongresinde, “...bizim iktidara gelişimiz güvenin ve emniyetin tam teessüsü devri olacaktır. Birçok vatandaşlarımın partizanliktan çok ıstırap çektiklerini bilirim... İktidar değişmesi olursa yıllardan beri bunca eziyet çekmiş olanların kanun dışı tedbirlerle intikam alma hislerine şimdiden karşı durmazsak memlekette huzur ve emniyetin tesisi gibi bir ana davamız gerçekleştiremeyiz... 3-5 kendini bilmezin tahriklerini tüm vatandaşlara teşmil etmeye kalkmak milletimizin birliğine zararh olacaktır." (İnönü,1956, s. 17.)

Bunun üzerine muhalefette bulunan partilerin birleşmesini, "Milli Muhalefet Cephesi" olarak adlandırılması ve İnönü'nün propaganda söylevine Ege'den başlaması ve buna 'Büyük Ege Taarruzu' adının verilmesi, içte milli

\footnotetext{
11 Haziran 1958 tarihnde CHP ilçe Kongresinde yaptığı konuşma,

211 Kasım 1959, Beypazarı ilçe kongresi nutku,
} 
birlik ve bütünlüğü bozan bir gruba karşı milli müdafaa havası yaratılmasının göstergesidir. Bu durum Zafer gazetesinde eleştirilmiştir. (Zafer, 2 Mayıs 1959.)

İnönü 18 Nisan 1960 tarihinde TBMM'de yaptı̆̆ bir konuşmada, “...eğer bir idare insan haklarmı tanımaz, baskı rejimi kurarsa o memlekette ayaklanma olur. ..eğer insan haklar yürütülmez, vatandaş hakları zorlanırsa, baskı rejimi kurulursa ihtilal behemehal olur...Şimdi arkadaşlar, şartlar tamam olduğunda milletler için ihtilal meşru bir haktır." demiştir. (İnönü, 1956, s.86.)

İnönü 23 Nisan 1960 tarihinde, “...her meşru ihtilalin, ilk gününden milletin meşru hakkına, meşru arzusuna isnat etmesi şarttır ve bu ihtiyaca tercüman olacak bir milli heyetin vücuda getirilmesi lazımdır. Bu heyet, teşekkül ettiği andan itibaren, millet haklarmın gaspına teşebbüs ettiği için gayri meşru duruma düşmüş eski idarenin temsilcileriyle mücadele haline girmiştir. Türk ihtilalinde bu mücadele vatan istila eden düşmana karşı olan savaş kadar şiddetli ölçülere varmıştır. Demek oluyor ki millet hâkimiyet düşmanları, ister içerde gayri meşru hale gelmiş idare, ister dışardan vatanı istilaya kalkışan yabancı kuvvet olsun, millet için aynı derecede yıkıcıdır ve ayn şiddetle millet tarafindan karşılanmak lazımdır." (İnönü,1956, s. 91) diyerek iç siyaset konusunu milli birlik, bütünlük ve bağımsızlık konusu olarak alg1ladığını göstermiştir. (Bu açıklamalar DP tarafından halkı isyana teşvik, milli bütünlüğü bozmak olarak algılanmıştır.)

İnönü başkanlığında CHP, 25 Nisan 1960 tarihinde Meclis Grubu toplantısında, DP'nin baskı rejiminin artık partiler arası siyasi bir mücadeleden çıtığı, "Türk milleti ile onun haklarını gasp etmeye çalışan bir avuç insan arasında" (İnönü, 1956, s.92) olduğu beyan edilerek sorunun bir nevi bağımsızlık mücadelesi haline geldiğine değinilmiş ve halk hareketlerini 'vatani' olarak yorumlamışır.

Dinin siyasete alet edilmesi, CHP için milli bütünlüğü ve bağımsızlığı bölücü bir faaliyet olarak değerlendirilmektedir. 11 Ocak 1960 tarihinde İnönü'nün Bilecik'te yaptı̆̆ basın toplantısında; “dini siyasete alet etmek hareketinin her türlü zararmı görerek, cemiyeti buna karşı savunmak, milli mücadelenin ve cumhuriyetin temeli olmuştur. Osmanl İmparatorluğunun dini siyasete birinci defa alet etmesinden Imparatorluk batmış; ikincisinde vatan gü̧̈ kurtarılmıştır." (İnönü, 1956, s. 39.) diyerek DP'yi dini siyasete alet etmekle itham etmiş ve bunun milli bağımsızlık ve bütünlüğe aykırı bir faaliyet olarak değerlendirmiştir.1960 yılı başından itibaren iktidarı, Nurcuları korumaya başlamakla suçlamıştır. (Ulus, 15 Şubat 1960.) 
İktisadi meselelerde_de İnönü, “...bugün dış âlemle ilişkilerimiz, siyaset ve iktisat sahalarnda prensiplerde birbirimizin tesiri ve bilgisi içinde yaşamak zorunludur. Paranın kıymetini düşürüp, dış âlemin memleket aleyhine türlü müdahalelerine yol açlmaktadır. Memleketin menfaatine ve itibarnna zarar veren eksiklikleri düzeltmek lazımdır." (İnönü, 1956, s.40.) diyerek iktisadi bunalımın Türk dış siyaseti ve milli bağımsızlık açısından önemini dile getirmiş; DP'nin ekonomik kararlarının bağımlılığa yol açtığını iddia etmiştir.

Bununla beraber, 1959 yılında DP'nin ABD ile yaptığı iki garanti anlaşması da muhalefet tarafından, "ABD'ye kapitüler haklar tanıdığı" gerekçesiyle eleştirilmiştir. (Ulus, 17 Ocak 1959.)

\section{DP'nin Milli Güvenlik Anlayışı}

13 Ekim 1957 tarihinde henüz seçimlerden önce Namık Gedik, yaptığı bir konuşmada; “...oylar lehimize tecelli ederse, milli varlımizı bilerek bilmeyerek tahribe yeltenen, inkâr ve iftirayı mubah sayan muhalefeti mahkûm etmiş olacaktır" (Erer, 1963, s. 303) diyerek muhalefeti milli varlı̆g tehdit eden bir unsur olarak gördüklerini dile getirmiştir.

Menderes'in 20 Ekim 1957'de İzmir'deki hitabesinde ise, “...siyasi buhran, soysuzlaşmuş bir muhalefetin hareketlerinden başka bir şey değildir. Muhalefet, vatanperverlik icaplarma, kanunlara, nizamlara, asayiş, emniyet ve istikrara riayet ettiği, milli mevcudiyetimizin temel ve teminatın sarsmak gayelerine bağh kalmaya karar verdiği anda, Türkiye'de siyasi buhran dedikleri kendi kışkırtıcllklarmmn ve kendi kuru gürültülerinin derhal yok olduğunu ve uydurma vaveylalarn, komedyaları, sahne tertiplerinin derhal ortadan kalktı̆̆ın görürler. Moskova radyosu mütemadiyen muhalefete rey verilmesini tavsiye etmektedir....Moskova radyosunun maksadı bu siyasi boğuşmada mümkün olduğu kadar tahribatın fazla olmasıdır." (Erer, 1963, s.318-319.) demiştir. Bununla hem CHP’yi bölücü ve isyana kışkırtıcı hem de komünizm taraftarlı̆̆ıyla suçlamıştır.

DP Meclis Grubu, 14 Kasım 1957 tarihinde bir bildiri yayılayarak; "memleketimizin maddi ve manevi huzurunun iadesi, vatanin ve rejimin selameti ve amme hizmetlerinin iyi ve süratli yürütülmesi için lüzum görülecek kanun ve idari tüm tedbirlerin alınması"nı (Zafer, 15 Kasım 1957) ittifakla karara bağlamıştır. Bununla alınacak kararların maddi ve manevi huzurunun iadesi, vatanın ve rejimin selameti amacını taşıyacağı bildirmek istenmiştir. CHP'nin buna cevabı, Ulus gazetesinde söyle dile getirilmiştir: Menderes rejimi diktatörlüğe 
kaymaktadır. Diktatörler, hasta cemiyetlerin patolojik şartlarından veya bir vatan tehlikesinden, kaybedilen savaşların sonunda ortaya çıkmaktadır. Böyle bir durum söz konusu değildir. Ancak siyasi hayat şeklimize adeta ihtilalkarane bir üslup verilmek üzeredir. (Karaosmanoğlu, 1957, s.1) CHP Meclis Grubu, 28 Aralık 1957'de yayınladığı bildiride, 'rejim davasında eşit şartlarda seçim emniyeti, adalet istiklali ve basın hürriyeti'nin önemini vurgulayarak, hükümetin son aldığı kararları eleştirdi. (Ulus, 29 Aralık 1957). Menderes ise Meclis Grubunda yaptığı bir açılama ile "hürriyetin hududu olması lazım gelir; aksi halde anarşiye dönüşür" diyerek özgürlüklerin sınırland1rılması gerektiğine dikkat çekti.

Ulus gazetesini, 19 Mayıs 1958 tarihinde 'Bursa Nutku'nu yayınlamasını da "memlekette isyan havası yaratıldığı" gerekçesiyle suçladı. (TBMM Zabıt Ceridesi, s.173-174.)

28 Nisan 1960 olayları sonrasında ise Menderes, olağanüstü olarak toplanan DP Meclis Grubunda ..."üniversiteye gireceğiz, bize vatan lazımdır. Siyaset yapmak için, üniversite kurmak için vatan lazımdır. Fïlen ihtilal içindeyiz, ihtilalin kendi içinde mantıklı icapları vardır. Biz bunları yaparken mümkün olduğu kadar memleket menfaatlerini müdafaa etmek ve her yerde memleketi lokalize etmek suretiyle neticeler alma yolunda tertiplerimizi almaktayız. Bu gazeteleri kapatacağız, bu adamları içeri tıkacağız, üniversiteye gireceğiz..." demiştir. (Albayrak, 2004, s. 536-537. ( DP MGMZ, XI, cilt: 304, s. 9-18.)

Ayrıca bu günlerde yaptığı bir radyo konuşmasında hükümetin aldığı tedbirlerin "milli bünyeye arı olacak musibetlere karşı koymak" olarak bildirmiştir. (Erer, 1963, s.409.)

Menderes 1960 yılının Mayıs ayının başlarında yaptığı bir radyo konuşmasında, CHP'yi halkı ayaklandırarak, "NATO'ya müteveccih bir tertip olarak millete ve dünyaya jurnal etmekle" suçlamıştır. Radyo gazetesi ise, 'CHP'yi ihtilal bayraktarlığı yapan tehlikeli bir fesat ocağı' olarak nitelemiştir. ( Aydemir, 1991, s.404.)

Menderes, 1 Mayıs 1960 günü yaptı̆̆ bir konuşmada, İstanbul ve Ankara'da çıkan olayları, NATO'nun toplandığı zamana denk getirerek Türkiye'nin prestijini Batılılar önünde düşürmenin amaçlandı̆̆ını ve bunun komünist usullere göre hesaplanmış bir hareket olduğunu dile getirmiştir. Böylelikle CHP liderliğinde yapıldığına inandıkları halk hareketlerini komünist, dış mihraklarca düzenlenmiş bir hareket olarak nitelendirmektedir. (Erer, 1963, s. 415.) 
TBMM İç Tüzük değişikliği 27 Aralık 1957 tarihinde kabul edilerek milletvekillerinin denetim görevlerini zorlaştıran hükümler getirilmiş; bu düzenlemeye karşı CHP'li Ferda Güley, "bu tadille hâkimiyet, hükümetin olacaktır” yorumunu yapmıştır. (Cumhuriyet, 28 Aralık 1957.)Ayrıca, sözlü sorular sadece Cuma günleri, en fazla bir saat müzakere edilebilecek, bakanlar bu sorulara genel çıkarlara aykırı gerekçesiyle isterlerse cevap vermeyeceklerdir. Daha önceki tüzükte, dokunulmazlıkların kaldırılması, Anayasanın 12. ve 27. maddelerine gönderme yaparken, artık bu zorunluluk kaldırılmış; basit suçlardan dahi dokunulmazlıkların kaldırılması mümkün hale getirilmiştir. Yine aynı kanunla meclisten çıarma cezasının üst sınırı, 3 oturumdan 12 oturuma yükseltilmiş; bazı hallerde ise tüm maaşın kesilmesine varan cezalar öngörülmüsstü. Kürsüde konuşan milletvekillerinin hoşa gitmeyen sözleri ise, "lisan temizliğinden ayrıldıkları" gerekçesiyle ve çoğunluğun kararıyla tutanaklardan çıkarılabilecekti.(Pars, 2005, s. 149)

İktidar ve muhalefet arasındaki çatışma Tahkikat Komisyonu'nun kurulmasıyla daha da alevlenmiştir. 12 DP'li milletvekilinin DP Meclis Grubunda, “CHP'nin tatbik etmekte bulunduğu yıkıcı hareket ve teşebbüslerinin millet ve memleket emniyet ve selametini ve rejimi tehdit eder mahiyeti ve 14 Temmuz Irak hadiselerinden bu yana açıtan girişmiş bulunduğu ihtilalci davranışlarn muvacehesinde..." dokuz kişilik bir komisyon seçilerek durumu tetkik etmesini önermeleri, Tahkikat Komisyonunun düşünsel temelini oluşturmuştur. (Albayrak,2004, s.519. DPMGMZ, XI, cilt: 234, s. 122-123.)

Bunun üzerine, 11 Ağustos 1958 tarihinde DP Meclis Grubu, CHP'lileri “...hükümete karşı halkı galeyana getirme, fiili tecavüzlere tahrik ve teşvik etme, hücre teşkilatı kurarak yıkıc ve kanun dışı faaliyetlerde bulunma, memleketin iktisadi, içtimai hayatım tehlikeye maruz bırakma.." gibi suçlamaları soruşturması için bir komisyon kurulmasını teklif etmiştir. (Ulus, 17 Nisan 1960.)

12 Nisan 1960'da olağanüstü bir toplantı yapan DP Meclis Grubu, CHP hakkında bir tahkikat kurulu açılmasına karar vermiş, CHP'nin seçim dışı yollarla iktidara gelmek için hücre örgütü kurduğu ve silahlanarak isyan hazırlı̆̆ içine girdiği gerekçe gösterilmiştir. CHP de bir önerge hazırlayarak, başbakanın Yüce Divana sevkini istemiş; ancak kabul edilmemiştir. (Ulus, 17 Nisan 1960.)

Tahkikat Komisyonu, 18 Nisan 1960 tarihinde kurulmuştur. Komisyonun CHP'ni soruşturma nedeni: “...memleketin siyasi, iktisadi ve mali, içtimai haya- 
tını tehlikeye maruz bırakan basın ve CHP'nin yıkıcı bölücü faaliyetlerini incelemek"tir. Komisyon, 2247 sayılı yasanın, 19 Nisan 1960 tarih ve 10484 sayılı

Resmi Gazete'de yayınlanmasıyla göreve başlamıştır. Üyeler: “1) Ahmet Hamdi Sancar, 2) Osman Kavuncu, 3) Bahadır Dülger, 4) Sait Bilgiç, 5) Cavit Asena, 6) Kemal Biberoğlu, 7) Kemal Özer, 8) Hilmi Dura, 9) Ekrem Anit, 10) Nusret Krişçioğlu, 11) Turhan Bahadır, 12) Selami Dinçer, 13) Himmet Ölçmen, 14) Necmettin Önder, 15) Nüzhet Ulusoy'dur. (Ahmad,1976, s. 208.)Komisyonun görevi muhalefetin faaliyetlerini ve basın aleyhinde ileri sürülen suçlamaları soruşturarak üç ay içerisinde rapor etmekti. İlk elde üç yasak kararı aldı: 1) partilerin kongreleri, toplantıları, tüm siyasi faaliyetleri, yeni örgüt kurmaları yasaklanıyordu. 2) Komisyon'un faaliyetleriyle ilgili tüm yayınlar yasaklanıyordu. 3) TBMM'nin tahkikat kararıyla ilgili müzakerelerin yayımı da yasaklanıyordu." (Cumhuriyet, 19 Nisan 1960; Yılmaz, 2019, s. 236245)

İnönü'nün bu kararlara ve uygulamalara verdiği yanıtta şu cümleler, bir ay sonra olacaklar hakkında işaret vermekteydi: “...şartlar tamam olduğunda, millet için ihtilal meşru bir haktır..." (Erer, 1963, s. 396.)

Yukarıda da aktarıldığı gibi 27 Mayıs sabahı "Türk Silahlı Kuvvetlerinin ülkenin yönetimin, ele aldığını" duyurmuş, Türkiye'de çok partili siyasal rejime bir süreliğine ara verilmiştir.

\section{Sonuç}

1957-1960'lı yıllar DP'nin iktidarının son dönemi ve Uluslararası ortamda yaşanan değişimler açısından önemli bir dönemdir. Muhalefetin DP'ye yönelik eleştirileri iyice artmış, sadece dış politika alanında değil iç politikadaki birçok konu da milli güvenliği tehdit olarak algılanmaya ve söylemlerde yer almaya başlamıştır. Gerek muhalefet gerekse iktidar arasında çatışmalar daha da keskinleşmiştir.

Dış politika hususunda keskin ayrımların çok olmadığı iktidar ve muhalefet çatışması, iç siyasal ortamın koşulları gereği propaganda söylemlerini milli emniyet, milli birlik ve bütünlük gibi kavramlarla meşrulaştırma yoluna gitmişlerdir. Özellikle bağımsızlık mücadelesini nispeten yakın bir zaman önce vermiş bir ülkede bu kavramların hayati bir önem taşıdığı muhakkaktır. 
Demokrat Parti, iç isyan ve içte birlik ve bütünlüğün zedelenmesi; komünizm taraftarlığı gibi konulara yoğunlaşarak CHP'nin faaliyet ve söylemlerini eleştirirken; CHP, DP'yi, ekonomi ve dini siyasete alet etmekle suçlayarak bunu milli emniyet konusu haline getirmiştir.

Özetle denilebilir ki; söz konusu dönem boyunca hem DP'nin hem CHP'nin güvenlik söylemleri, sadece devlet olarak dışa karşı bir güvenlik olarak değil; aynı zamanda iç siyasal ortamın istikrarı, sosyal ve ekonomik koşulları da içermekte, 'milli emniyet', 'milli birlik ve bütünlük' anlayışları iç siyaset alanında birbirlerine zit bir çizgide seyretmekte ve kendi görüşlerini meşrulaştırma vasıtası olarak kullanılmaktadır. 


\section{EXTENDED ABSTRACT}

\section{Security Discourse in the Discussions Between the Democratic Party and the Republican People's Party (1957-1960)}

Cemile Burcu Kartal

Erzurum Atatürk University

The concept of security was born in the 1940s under the name of Strategic Studies and turned into a sub-discipline of International Relations, and today it is involved within the field of Security Studies. From the 1940s to the 1980s, security was identified with the power policies implemented by the states within the framework of military problems.

Sönmezoğlu defined the purpose of security in a narrow sense as taking measures that would not require the defence of the motherland directly in relation to the matter of survival. The security purpose of a country is generally in conflict with that of another country or countries. The purpose of security is affected by the change in conditions. The fact that there is a relationship between security and the political regime, or that democratic countries fight less with each other, is evident in the studies. But the concepts of economic capacity, economic dependence / interdependence whose significance is highlighted in terms of national security in the recent security studies are more frequently becoming the subject of analyses in the global world. According to the literature, the concept of security has begun to be understood beyond the military problems that concern the states since the 1980s. Since the end of the 1980s, an understanding has developed that security is threatened by problems such as poverty, population surplus, environmental problems, political pressures, crime, economic instability, disease, migration, etc., rather than military problems merely.

The security rhetoric of the ruling Democratic Party (DP) and the main opposition Republican People's Party (CHP) in their own discourses and those directed against their opponents, and what issues they included in the scope of national security have been examined in the article. 
The period between 1957-1960 which was the last period of the DP's power was important in terms of the changes in the international environment. Turkey's foreign policy between 1957 and 1960 can be roughly grouped as relations with the USSR, relations with the United States and NATO and the relations with Greece and the Middle East. In this process, Turkey has pursued an uncompromising pro-Western policy. When we first looked at relations with the USSR, there was a relative softening after Stalin's death. In a note dated May 30, 1953, the USSR declared that it had given up on its demands following World War II and expressed its hope that relations would improve. Although Turkey responded to this note with the bloc policy, the economic relations still began and continued to increase. Nevertheless, the Syrian crisis in 1957 and the coup in Iraq in 1958 strained relations with the USSR. In 1957, with the deployment of Jupiter missiles in Turkey, a missile crisis began that would reach the climax with the U-2 crisis and last until 1962. On the other hand, the relations with the United States began with The Truman Doctrine after the Second World War. Turkey was important for the security of the Eastern Mediterranean and Middle East from the point of view of the United States. Especially after joining NATO, Turkey's foreign policy developed within this framework. Turkey also pioneered the establishment of the Balkan Pact in the Eastern Mediterranean and the Baghdad Pact in the Middle East.

Economic difficulties in domestic policy at that time and the DP's following a more authoritarian regime further strained relations with the opposition. As a matter of fact, after these developments, the elections were drawn to an early date. The normal time for the general elections after 1954 was May 1958, but the government was seriously concerned that the economic situation was deteriorating and thus decided to hold the elections on October 27, 1957 , in order to break the negative impact of this situation on the people's votes.

General elections were held on 27 October 1957, and the DP won 424 seats in parliament with $47 \%$ of the votes. CHP entered the parliament with 178 seats while CMP with 4 seats and HP with 4 seats. The most important development that emerged after the 1957 elections was that the CHP began to conduct a tougher and more active opposition with increased votes.

During the period, the opposition's criticism of the DP continued to increase, and many issues, not only in the field of foreign policy, but also in 
domestic policy, began to take part in the rhetoric in the context of threat against national security. Clashes between the opposition and the government have become even more bitter. Even though the basic opinions of the two parties on foreign policy were not very contradictory to each other in accordance with the conditions of the period in question, they took a contrasting line with each other in the field of domestic politics, including their understanding of 'national security', 'national unity and integrity'.

The article also examined the security understandings of the two parties in this whole process. In the first chapter, the concepts were outlined and a brief analysis of the internal and external political environment was given; in the second chapter, the discourses of both the DP and the CHP on the issue were examined. Discussions were evaluated as much as possible through first-hand sources through the news and speeches of the leaders reflected in the press.

When the results of the study were examined, it was observed that the conflict of power and opposition did not have many sharp differences in foreign policy, but in accordance with the conditions of the internal policy environment of the time, they resorted to legitimizing their propaganda rhetoric with concepts such as "national security", "national unity and "integrity". Especially in a country that has fought for independence recently, these concepts were of vital importance.

The DP criticized the activities and rhetoric of the CHP, focusing on issues such as internal rebellion and damage to internal unity and integrity; supporting communism while the CHP accused the DP of using religion and economy as an instrument for politics, making it a matter of national security.

During the period in question the security rhetoric of both the DP and CHP included not only the external security, but also the stability, social and economic conditions of the internal political environment, and the ideas of 'national security', 'national unity and integrity' followed opposite lines to each other in the field of domestic politics and are used as a means of legitimizing the views and opinions by both parties.

\section{Kaynakça / References}

Ağaoğlu, S. (1967). Arkadaşım Menderes. İstanbul: Baha Matbaası.

Ahmad, F. (1976). Türkiye'deçok partili politikann açılamal kronolojisi 1945-1971. İstanbul: Bilgi Yayınevi. 
Albayrak, M. (2004). Türk siyasi tarihinde Demokrat Parti. Ankara: Phoenix Yayınevi. Aydemir, Ş. S.(1991). İkinci adam. İstanbul: Remzi Yayınevi.

Armaoğlu, F. (2002). 20. Yüzyl siyasi tarihi. İstanbul: Alkım Yayınevi.

Baldwin, D. (1997). The concept of security.Review Of International Studies, 23, 5-26.

Bekata, H. O.(1960). Birinci Cumhuriyet biterken. Ankara: Çı̆̆ır Yayınları.

Erer, T. (1963). On yılın mücadelesi. İstanbul: Ticaret Postası Matbaası.

Bilgin, P (2003) Individual and socieatal dimansions of security. International Studies Review, 5, 202-222.

Bulut, S. (2009). Üçüncü dönem demokrat parti iktidarı (1957-1960): Siyasi baskılar ve tahkikat komisyonu, Akademik Bakış, 2(9), 125-145.

Erhan, Ç. (2005)1945-1960 Batı bloğu ekseninde Türkiye. ed B. Oran, Türk dış politikası, İstanbul: İletişim Yayınları.

Eroğul, C (2003). Demokrat Parti tarihi ve ideolojisi. Ankara: İmge yayınevi.

Erdemir,S. (1996). Muhalefette İsmet İnönü 1950-1956. (c.1, der. Sabahat Erdemir,)İstanbul: Siralar Matbaası.

Farrell, T. (2002). Constructivist security studies: sortrait of a search program, International Studies Review, 4(1), 49-72.

Furat, M. (2005). Yunanistan'la ilişkiler. Ed. B. Oran, Türk dış politikası, İstanbul: İletişim Yayınları.

Fırat, M. ve Kürkçüoğlu, Ö. (2005). Ortadoğu'yla ilişkiler. Ed. B. Oran, Türk dış politikası, İstanbul: İletişim Yayınları.

İnönü, İ. (1956) Muhalefette İsmet İnönü III. (ed. S. Erdemir, ) İstanbul.

Karaosmanoğlu, Y. K, (1957). DP başkanına açı mektup. Ulus.

Lantis, J. (2002). Strategic culture and national security policy. International Studies Review, 4(3), 87-113.

Oran, B (2005). Batı avrupa ile ilişkiler. Ed. B. Oran, Türk dış politikası, İstanbul: İletişim Yayınları.

Pars, V. (2005). Demokrat Parti döneminde siyasal örgütlenme. Yayınlanmamış Yüksek Lisans Tezi, İstanbul Üniversitesi Sosyal Bilimler Enstitüsü Uluslararası İişkiler Anabilim Dalı, İstanbul.

TBBM Tahkikat Encümenlerinn Vazife ve Salâhiyetleri Hakkında Kanun (28 Nisan 1960), Resmi Gazete, sayr: 10491.

Sander, O. (1996). Siyasi tarih. Ankara: İmge Yayınevi.

TBMM. (1958). TBMM Zabut Ceridesi, XI, cilt:4, kısım:1, s. 173-174.

Tellal, E (2005). SSCB ile ilişkiler. Ed. B. Oran, Türk dış politikası. İstanbul: İletişim Yayınları. 
Yıldırım, T. (2019). Muhalefet ve basın1957-1960 dönemi ilişkileri çerçevesinde demokrat parti. Yayınlanmamış Yüksek Lisans Tezi, İstanbul Üniversitesi Sosyal Bilimler Enstitüsü Tarih Anabilim Dalı, İstanbul.

\section{Kaynakça Bilgisi / Citation Information}

Kartal, B, C. (2021). Türkiye'de 1957-1960 arası dönemde Demokrat Parti ve CHP arasındaki tartışmalarda güvenlik söylemi. OPUS-Uluslararası Toplum Araştırmaları Dergisi, 17(34), 1355-1382. DOI: 10.26466/opus.833529 